\title{
An Assessment of CPTED Principles in Relation to Bullying Behaviour*
}

\author{
Azna Abdul Wahab ${ }^{1}$, Siti Rasidah Md Sakip ${ }^{2 \#, ~ H a l m i ~ Z a i n o l ~}{ }^{2}$ \\ ${ }^{1}$ Faculty of Architecture Planning and Surveying, Universiti Teknologi MARA, Shah Alam, Selangor, Malaysia \\ ${ }^{2}$ Faculty of Architecture Planning and Surveying, Universiti Teknologi MARA, Perak, Malaysia \\ Email: azna.abdulwahab@yahoo.com, "sitir704@perak.uitm.edu.my, halmizainol@gmail.com
}

How to cite this paper: Wahab, A. A., Md Sakip, S. R., \& Zainol, H. (2018). An Assessment of CPTED Principles in Relation to Bullying Behaviour. Advances in Applied Sociology, 8, 25-48.

https://doi.org/10.4236/aasoci.2018.81002

Received: November 8, 2017

Accepted: January 13, 2018

Published: January 16, 2018

Copyright (c) 2018 by authors and Scientific Research Publishing Inc. This work is licensed under the Creative Commons Attribution International License (CC BY 4.0).

http://creativecommons.org/licenses/by/4.0/

Open Access

\begin{abstract}
This paper presents a preliminary study examining the potential influences of building design on bullying behavior and experiences, of a sample of Malaysia secondary school students. Bullying in school may be an early stage of the developmental sequence that serves as a strong predictor of delinquency and future crime. Through the discussion of findings in previous studies, environmental design approach is as one of the methods to bring down the level of crime in school. Crime Prevention through Environmental Design (CPTED) is an approach that uses environmental design as a tool to reduce crime from both the physical and the psychological aspects. The features of physical environment such as street layout, building design, lighting and physical decay can affect the occurrence and behaviour of criminals. The shortcomings in the physical environment could open up the opportunity for offenders. Thus, this study seeks to determine if there is a possibility that the actual physical environment in which students spend greater part of their day can affect behaviour, which in turn, can lead to violence in school. A survey was conducted at four secondary schools in Shah Alam, Selangor with a random sample of 406 students from Form 1, Form 2 and Form 3 involving the observation of 32 school blocks. Three principles of Crime CPTED were analyzed in the school environment. The results indicated that there is a significant difference in territoriality and school maintenance which results in the forming of the negative environment in the schools. It was found that this, in turn, affects the frequency of bullying occurring among the students in school.
\end{abstract}

\section{Keywords}

School, Bullying, CPTED, Physical Environment

${ }^{*}$ A preliminary study examining the potential influences of building design on bullying behavior and experiences, of a sample of Malaysia secondary school students. 


\section{Introduction}

The quality of school life among the children in the school is disturbed by the phenomenon of bullying, and it has been recognized as a serious problem among the school society (Berthold \& Hoover, 2000). Bullying can be defined as negative actions that repeatedly occur over a period directed against another student who has difficulty in defending himself or herself (Olweus, 1994; Wan Ismail, et al., 2010). From past research, at least 5 percent of the students in both primary and secondary schools were bullied weekly or more often in North America, Australia, Japan, Scandinavian countries and several countries in Europe (Roland \& Galloway, 2002). The United States Department of Justice and the National Association of School Psychologists (NASP) estimated that 160,000 children missed school each day due to the fear of the bullies (Newman-Carlson \& Horne, 2004). In the year 2013, approximately 3 percent of students aged between 12 and 18 years old are reported afraid of being attacked or harmed at school or on the way to and from school (Robers, Zhang, \& Morgan, 2015).

Malaysia also does not behind from this phenomenon, and it has been a concern, especially for parents. Malaysia is a country with multi-ethnic, multicultural, and multilingual society. It is a country with the majority in Muslim, with significant Buddhist, Christian, Hindu religious minorities also being present. The nature of secondary education system in Malaysia is categorized into three types which are National Secondary School, National Type Secondary School and Secondary Technical and Vocational School. In addition, there are also schools which specifically for single-sex. As for National Secondary School, there is a mixture of ethnic, gender and linguistic in school. The average size of schools regarding student enrolment is 35 to 40 students per class. In 2017, it was reported Selangor had recorded as the highest number of "hotspot" school for bullying cases as many as 76 schools, followed by Johor (63), Negeri Sembilan (40), Pahang (37) and Pulau Pinang (37) (Bernama, 2017). Until Jun. 2017, it was recorded 872 bullying cases occurred in the school (Raja Zaid, 2017). Recently in Jun. 2017, two students were dead because of bullying. One of the students had been beaten extremely using a belt, rubber pipe and hanger including abused using steam iron ( $80 \%$ body burns). The abused lasts up to two days.

Traditionally, bullying has not been viewed as a criminal act and has either been ignored or treated as a disciplinary matter in schools. In the meantime, there is no implementation of strong national policy that is fighting for school bullying, and the issues are left to individual schools. However, Malaysia government is in all effort to combat bullying in school. The victims apparently helped and supported by school counseling. The perpetrator will be dealt with criminal law and if serious can be expelled from school.

Bullying makes the lives of its victims miserable. It undermines their confidence and destroys their sense of security. It can also affect children and young people's attendance and progress at school. And there's evidence that, for some people, being bullied regularly as a child can also be linked to emotional prob- 
lems that considered a serious problem among the victims which included high levels of anxiety, depression, (Hawker \& Boulton, 2000; Nakamoto \& Schwartz, 2010; Reijntjes Kamphuis, Prinzie, \& Telch, 2010; Ken Rigby, 2003) and suicidal thinking (Rigby, 2003; Sourander, et al., 2011).

The previous researchers mostly focus on the larger scope which in neighbourhood context. A review of 122 evaluations of crimes prevention project by Poyner (1993) indicated that over half of the area of environmental design (24 out of 45) demonstrated the reduction of crimes. The evaluation was focused on lighting, fencing, design changes to improve surveillance opportunities, the cleanup of neighbourhoods, street changes, wider market gangways, electronic access control and modification. CPTED is an increasingly current approach and is being implemented on a global scale (Cozen, et al., 2005). Researched by Rasidah, Johari, Najib, \& Salleh (2012) had shown high CPTED practices are able to reduce the fear of crime in the neighbourhood area. However, the crime in school should be noted as a serious problem as it could lead to criminal activity in the future (Andershed, Kerr, \& Stattin, 2001; Min, et al. 2011; Olweus, 2011; Renda, Vassallo, \& Edwards, 2011; Sourander, et al., 2011). Although physical environment is considered to be an important factor that affects crime in school in environmental criminology, there is not much of research in school crime context on how environmental approach may help in reducing school crime and increasing safety in school. Wilcox, Augustine, and Clayton (2006) had studied on physical environment and crime in Kentucky Schools. Differently, with Wilcox method which is the observation was more focus on an element in the main office, this paper method was more focus on an element in each building in school. Thus, this paper seeks to determine in a school context if there is a possibility the actual physical environment in which students spend the greater part of their day can affect behaviour, which in turn, can lead to school violence.

\section{Literature Review}

\subsection{Definition of Bullying and Types of Bullying}

Bullying can be defined as negative actions that repeatedly occur over a period directed against another student who has difficulty in defending himself or herself (Olweus, 1994.; Wan Ismail, et al., 2010). Negative actions referred to behaviour that was intended to inflict harm, injury, pain, or discomfort upon another individual (Atlas \& Pepler, 1998). Meanwhile, Atlas \& Pepler (1998) defined bullying as a form of social interaction in which there was an implied imbalance of power or strength in the interaction. The power of imbalance in bullying may not be limited to physical size and may be presented in the tone of voice, the physical stance of a bully or the number of children take part as bullies and the support of peers who were involved (Atlas \& Pepler, 1998). Wi et al. (2009) defined bullying as repeated, ill-negative behaviours by one or more students directed against a student who has difficulty defending himself or herself. Therefore, bully will take places when there are imbalance powers between another 
people with negative action and has difficulty to defend on their own. Bullying behaviour may take many forms such as physical, verbal, (Olweus \& Mortimore, 1993) and relational or social (Crick, et al., 1995). Physical bullying, such as hitting, pushing and kicking, and verbal bullying, such as name-calling and teasing in a hurtful way, are usually considered to be a direct form, while relational bullying refers to an indirect form of bullying, such as exclusion and spreading rumors (Espelage, Bosworth, \& Simon, 2000; Wang, Iannotti, \& Nansel, 2009). Verbal bullying was the most widely performed type of bullying (Boulton, Trueman, \& Flemington, 2002; Mohamad Salleh \& Zainal, 2014; Rigby, 2008) that can be done quietly and covertly where the children are able to avoid detection and punishment (Atlas \& Pepler, 1998). Boys were more involved in physical bullying, whereas girls were involved in relational bullying (Wang, et al., 2009).

\subsection{Delinquency and Physical Environment in School}

Creation of safe school environments has become a focus of prevention and intervention efforts in response to problems of bullying in schools. The sense of safety from any danger and perpetration is one of the important aspects that drive the quality of life of students. Feeling safe is important for a student to have a positive learning environment in school. Feeling of unsafe in school impacts mental health, absenteeism and academic success among the bullied (Hughes, Gaines, \& Pryor, 2014). Schools encounter vulnerabilities to their safety and security in four major areas; 1) the design, supervision and use of school space (Astor, Meyer, \& Behre, 1999; Durán-Narucki, 2008; Grana, et al., 2010; J Waller 2013; Kumar, M. O’ Malley, \& D. Johnston, 2008; Wilcox, et al., 2006), 2) the administrative operations and practices of the school (Vidourek, King, \& Merianos, 2016) 3) the neighbourhoods and surrounding communities served by the school (Bowes, et al., 2009; Lee \& Ha, 2015) and 4) the behavioural characteristics and histories of the students who are enrolled in the school (Atlas \& Pepler, 1998; Farrington \& Ttofi, 2011; Mohamad Salleh \& Zainal, 2014).

As per mention, crime also is believed to be related to the physical environment (Liebermann \& Kruger, 2004) as it plays an important aspect in the developing behaviours (Durán-Narucki, 2008). Some places in school are more exposed to crime than others because of inappropriate physical design, layout (Newman, 1972) and overlooked of unused spaces. The opportunity that exists due to lack of design, supervision and use of school space and environment encourage a criminal to act on a targeted victim (Liebermann \& Kruger, 2004).

Ecological theories of crime had suggested that both social and physical characteristics can affect the crime (Shaw, 1942). The built environment is believed to be one of the factors influencing crime and the level of fear of crime in society (Sakip, Johari, \& Salleh, 2012). According to Poyner (1983), human movement and behaviour are critically affected by the design and layout of the physical environment. Through daily interactions with the physical and social environment, individuals learn about their places in society, their value, appropriate and inap- 
propriate behaviour (Durán-Narucki, 2008). The role of physical environments such as street layout, building design, lighting and physical decay can affect the behaviour of crime (Wilcox, et al., 2006). Some places are more exposed to crime than others because of inappropriate physical design, layout (Newman, 1972) and overlooked of unused spaces. Crime is believed to be related to the physical environment (Liebermann \& Kruger, 2004) as it plays an essential aspect in the developing behaviours (Durán-Narucki, 2008). The opportunity that exists in an environment encourages a criminal to act on a targeted victim (Liebermann \& Kruger, 2004). In deciding whether or not to commit an act of crime, the environmental element is one of the factors considered by criminals (Anastasia \& John, 2007).

From the previous study, regarding school crime and influence of environmental design, they had study on physical features (Wilcox, et al., 2006), lighting (Lee \& Ha, 2015), land used (Lee \& Ha, 2015; Wilcox, et al., 2006), neighbourhood physical environment (Wilcox, et al., 2006) and building condition (Durán-Narucki, 2008; Kumar, et al., 2008) in school environment and it affect student behaviour. According to Skogan and Maxfield (1981), in Melde \& Esbensen (2009), the environment such lacks of maintenance as poorly kept buildings and unsupervised referred as "sign of crime", and people tend to fear with this environment which may develop a reputation for high levels of criminal behaviour. Several factors in the physical environment are perceived to impact on fear of crime including visibility and signs of neglected (Lee \& Ha, 2015; Lorenc, et al., 2013). Dirt, decay, graffiti, litter and other sign of neglect of the environment are seen as drivers of fear (Lorenc, et al., 2013; Wilcox, et al., 2006). A proper surveillance and lighting at night are able to improve the visibility of the area thus reducing the fear of crime (Kitchen \& Schneider, 2007; Perkins, Meeks, \& Taylor, 1992) as to create visual clarity to the surrounding area. Although most exterior spaces of elementary schools are high-visibility areas, the hottest spots were behind the areas of the building which were low in visibility (Lee \& Ha, 2015). A place which is not visible because of isolated which are obstructed by landscaping and building design are believed to increase the risk of attack, and hence fear (Lorenc, et al., 2013). Certain "hot spots" that indicated to be un-owned spaces such as hallways, dining areas, and parking lot where are the sights of more crime event and greater fear among students (Astor, et al., 1999). Astor, et al. (1999) claimed the presence sense of ownership of these locations has the potential to decrease the prevalence of victimisation in schools drastically. A good maintenance strategy directly impacts the fear of crime due to awareness of responsibility and caring for the targeted crime. It allows for the continued use of space for its intended purpose.

Studies by Shamsuddin, Bahauddin, \& Aziz (2012) had indicated a relationship between the outdoor physical environment of the school and the students' social behaviours. However, the limitation of this research is not to evaluate the negative social behaviour related to schools environment. Certain "hot spots" that indicated to be unowned spaces are where the sights of more crime event 
create greater fear among students (Astor, et al., 1999). The presence sense of ownership of these locations has the potential to drastically decrease the prevalence of victimization in schools (Astor, et al., 1999). Through these studies, victimisation occurs most likely when the adults are limited in their abilities to monitor. The school structure may play an important part in giving a chance for individual children to involve in bullying behaviours (Atlas \& Pepler, 1998). Craig, et al. (2000) reported that victimisation is most likely to occur in less structured environments. Studies showed that lower rates of school victimization were associated with the school safety interventions that are focused on improving the physical environment of the school (Johnson, 2009). Johnson (2009) concluded that physical environment appears to offer intervention opportunities to reduce school victimization.

\subsection{Crime Prevention through Environmental Design (CPTED) as an Approach to Decrease Bullying Cases}

Crime Prevention through Environmental Design theory promotes a sense of safety and decrease the incidence of crime in any given environment by reduction of opportunities for crime to occur. This reduction is achieved by employing physical design features that discourage crime, while at the same time encouraging legitimate use of the environment. It is an approached from both the physical and the psychological aspects at the same time. There is a growing body of research that supports the assertion that crime prevention through environmental design is effective in reducing both crime and fear of crime in the community (Cozen, Saville, \& Hillier, 2005). CPTED focuses on the relationships between people and environment. The behaviour and movement of human were significantly affected by the architectural design and layout of the physical environment (Poyner, 1983). The crime patterns due to human behaviour and daily routine were determined by environmental design factors (Felson, 2006). There are four principles in CPTED which is territoriality, surveillance, maintenance and access control. A review of 122 evaluations of crimes prevention project by Poyner (1993) indicated that over half of the area of environmental design (24 out of 45 ) demonstrated the reduction of crimes. The evaluation was focused on lighting, fencing, design changes to improve surveillance opportunities, the cleanup of neighbourhoods, street changes, wider market gangways, electronic access control and modification. CPTED is an increasingly current approach and is being implemented on a global scale (Cozen, et al., 2005). Researched by Rasidah, Johari, Najib, \& Salleh (2012) had shown high CPTED practices are able to reduce the fear of crime. Noted that improved territoriality, indicated school ownership, and improved surveillance are essential factors to a better perception of safety in school (Wilcox, et al., 2006).

Crime Prevention through Environmental Design (CPTED) is one of crime prevention that had been applied variously in the residential and commercial area. However, there is not much of research in school crime context on how 
environmental approach may help in reducing school crime and increasing safety in school. Table 1 shows the previous study on safe school and physical environment that indicated to be the element of the CPTED principle. Thus, this study sought to help determine if there is a possibility the actual physical environment in which students spend the greater part of their day can affect behaviour, which in turn, can lead to school violence in secondary school in Malaysia.

\section{Methodology}

The site selection for the present study is based on the highest number of perpe-

Table 1. Previous study on safe school and physical environment.

\begin{tabular}{|c|c|c|c|c|c|c|c|}
\hline \multirow[b]{2}{*}{ Authors } & \multirow[b]{2}{*}{ Aim } & \multicolumn{5}{|c|}{ Physical Environment } & \multirow[b]{2}{*}{ Result } \\
\hline & & $\begin{array}{l}\text { Land } \\
\text { Use }\end{array}$ & $\begin{array}{l}\text { Physical } \\
\text { features }\end{array}$ & $\begin{array}{l}\text { Use of } \\
\text { Spaces }\end{array}$ & Lighting & $\begin{array}{l}\text { Building } \\
\text { Condition }\end{array}$ & \\
\hline $\begin{array}{l}\text { Astor, Meyer, \& } \\
\text { Behre (1999) }\end{array}$ & $\begin{array}{l}\text { To identify the locations and } \\
\text { times of the most violent occur }\end{array}$ & & & $\sqrt{ }$ & & & $\begin{array}{l}\text { The violence occurred primarily in spaces such } \\
\text { as hallways, dining areas, and parking lots at } \\
\text { times when adults were not typically present. } \\
\text { The spaces tend to be "unowned" }\end{array}$ \\
\hline $\begin{array}{l}\text { Wilcox, Michelle } \\
\text { Campbell } \\
\text { Augustine, \& } \\
\text { Richard R. Clayton } \\
\text { (2006) }\end{array}$ & $\begin{array}{l}\text { To test the link between the } \\
\text { physical environment and } \\
\text { crime within the school } \\
\text { environment }\end{array}$ & $\sqrt{ }$ & $\sqrt{ }$ & $\sqrt{ }$ & & $\sqrt{ }$ & $\begin{array}{l}\text { Few features of the school or neighbourhood } \\
\text { physical environment are associated with } \\
\text { student-based measures of school } \\
\text { crime/misconduct }\end{array}$ \\
\hline $\begin{array}{l}\text { Grana, R. A., Black, } \\
\text { D., Sun, P., } \\
\text { Rohrbach, L. A., } \\
\text { Gunning, M., \& } \\
\text { Sussman, S. (2010) }\end{array}$ & $\begin{array}{l}\text { To examines the relationship } \\
\text { between the level of school } \\
\text { disrepair and substance use } \\
\text { among students attending } \\
\text { regular high school (RHS) and } \\
\text { alternative high school (AHS) }\end{array}$ & & & & & $\sqrt{ }$ & $\begin{array}{l}\text { Findings indicated that students attending } \\
\text { AHS with greater school disrepair were more } \\
\text { likely to report the use of marijuana and other } \\
\text { illicit drugs (i.e., cocaine, heroin). Students } \\
\text { attending RHS with greater school disrepair } \\
\text { were less likely to report smoking cigarettes }\end{array}$ \\
\hline $\begin{array}{l}\text { Katherine J. Waller } \\
\text { (2013) }\end{array}$ & $\begin{array}{l}\text { To determine the relationship } \\
\text { between level of school } \\
\text { violence and school physical } \\
\text { environment as perceived by } \\
\text { teachers }\end{array}$ & & $\sqrt{ }$ & $\sqrt{ }$ & & $\sqrt{ }$ & $\begin{array}{l}\text { The results of this study verified a significant } \\
\text { relationship exists between the school } \\
\text { environment and disruptive behaviours. There } \\
\text { was no relationship found between the school } \\
\text { environment and violent behaviours. Physical } \\
\text { state of a school environment in terms of the } \\
\text { age, state of repair, cleanliness, lighting, } \\
\text { heating and cooling, etc., to impact the } \\
\text { occurrence of disruptive behaviours as } \\
\text { perceived by teachers }\end{array}$ \\
\hline Lee \& Ha (2015) & $\begin{array}{l}\text { The relationship between } \\
\text { visibility and fear of crime in } \\
\text { environments using an } \\
\text { automated quantitative } \\
\text { analysis method }\end{array}$ & & & $\sqrt{ }$ & $\sqrt{ }$ & & $\begin{array}{l}\text { Locations for which fear of crime was reported } \\
\text { had lower levels of visibility compared to } \\
\text { locations not associated with fear of crime. The } \\
\text { rear areas of buildings; areas located near } \\
\text { newly built buildings; areas between buildings; } \\
\text { curved or recessed walls; parking areas; and } \\
\text { playgrounds were hot spots }\end{array}$ \\
\hline
\end{tabular}


Table 2. Crime index involved by students in Malaysia states.

\begin{tabular}{|c|c|c|c|c|c|c|c|c|}
\hline \multirow{2}{*}{ No } & \multirow{2}{*}{ States } & \multicolumn{6}{|c|}{ Year } & \multirow{2}{*}{ Total } \\
\hline & & 2010 & 2011 & 2012 & 2013 & 2014 & 2015 & \\
\hline 1 & Johor & 148 & 95 & 57 & 379 & 299 & 169 & 1147 \\
\hline 2 & Kedah & 234 & 1552 & 97 & 272 & 205 & 152 & 1112 \\
\hline 3 & Kelantan & 190 & 130 & 94 & 199 & 133 & 105 & 851 \\
\hline 4 & Kuala Lumpur & 108 & 106 & 125 & 147 & 165 & 94 & 745 \\
\hline 5 & Melaka & 53 & 37 & 13 & 125 & 90 & 51 & 369 \\
\hline 6 & Negeri Sembilan & 61 & 47 & 61 & 106 & 160 & 95 & 530 \\
\hline 7 & Pahang & 77 & 56 & 56 & 165 & 173 & 87 & 614 \\
\hline 8 & Perak & 127 & 84 & 90 & 210 & 146 & 114 & 771 \\
\hline 9 & Perlis & 36 & 26 & 49 & 57 & 39 & 25 & 232 \\
\hline 10 & Puau Pinang & 131 & 86 & 23 & 138 & 63 & 82 & 523 \\
\hline 11 & Sabah & 115 & 60 & 51 & 120 & 76 & 55 & 477 \\
\hline 12 & Sarawak & 121 & 69 & 82 & 137 & 104 & 115 & 628 \\
\hline 13 & Selangor & 369 & 218 & 58 & 269 & 313 & 276 & 1503 \\
\hline \multirow[t]{2}{*}{14} & Terengganu & 92 & 64 & 95 & 159 & 107 & 67 & 584 \\
\hline & Total & 1862 & 1230 & 951 & 2483 & 2073 & 1487 & 10086 \\
\hline
\end{tabular}

Source: The Royal Malaysia Police Bukit Aman.

tration range from 7 to 18 years in crime index cases reported by police over five years ago from the year 2010 until September 2015. Table 2 shows for the past five years, crime index data in 14 states in Malaysia. The highest reported crime index involved by students were in Selangor as much as 1503 cases and followed by Johor 1147 cases and Kedah 1112 cases. Crime cases are higher in Selangor because Selangor is an urban city with high population density and infrastructure of the built environment. Urbanization has created many social problems and crime had become a common phenomenon in all urban area (Adel, Salheen, \& Mahmoud, 2014; Ghani, 2017).

With the assumption of the number perpetration in school is linear with the number of bullying in school, Selangor is chosen as a location in this study. The selection of Selangor as site study is relevant due to the news reported in June 2017, the Ministry of Education had list as much as 402 schools nationwide which have been identified as having disciplinary issues among its students and Selangor states was recorded as highest bullying case and highest number of "hotspot" school (Bernama, 2017). Thus, Selangor states were chosen as the site study in this paper.

Thereafter, the data from the Selangor State Education Department was acquired to get the number of misconduct cases in Selangor district schools. Table 3 showed ten districts in Selangor, and Hulu Langat district was reported to be the highest contributors to the number of misconduct cases in Selangor 
Table 3. Number of misconduct in Selangor district.

\begin{tabular}{ccccccc}
\hline \multirow{2}{*}{ No } & States & \multicolumn{4}{c}{ Year } & Total \\
\cline { 3 - 5 } & & 2013 & 2014 & 2015 & 2016 & \\
\hline 1 & Sabak Bernam & 767 & 328 & 945 & 881 & 2921 \\
2 & Gombak & 3871 & 4723 & 7002 & 3473 & 19,069 \\
3 & Petaling Perdana & 7085 & 9272 & 21,757 & 7437 & 45,551 \\
4 & Kuala Langat & 2489 & 2573 & 2267 & 1807 & 9136 \\
5 & Sepang & 2383 & 5395 & 2227 & 1545 & 11,550 \\
6 & Kuala Selangor & 3845 & 4246 & 3785 & 3695 & 15,571 \\
7 & Hulu Langat & 18,280 & 20,029 & 14,796 & 15,143 & 68,248 \\
8 & Klang & 7066 & 8570 & 10,250 & 4104 & 29,990 \\
9 & Petaling Utama & 3447 & 6682 & 51,363 & 2027 & 17,319 \\
10 & Hulu Selangor & 3368 & 5065 & 7081 & 2948 & 18,462 \\
& Total & 52,601 & 66,883 & 75,273 & 43,060 & 237,817 \\
\hline
\end{tabular}

Table 4. Type of bullying cases in secondary school in Hulu Langat District. Source: PPD Hulu Langat, Selangor.

\begin{tabular}{|c|c|c|c|c|c|c|}
\hline \multirow{2}{*}{ No. } & \multirow{2}{*}{ Type of Bullying } & \multicolumn{4}{|c|}{ Year } & \multirow{2}{*}{ Total } \\
\hline & & 2013 & 2014 & 2015 & 2016 & \\
\hline 1 & Verbal Bullying & 13 & 8 & 11 & 26 & 58 \\
\hline 2 & Physical Bullying & 55 & 66 & 81 & 124 & 326 \\
\hline 3 & Sign Bullying & - & - & 8 & 4 & 12 \\
\hline \multirow[t]{2}{*}{4} & Social Bullying & 4 & 11 & 4 & 5 & 24 \\
\hline & Total & 72 & 85 & 104 & 159 & 420 \\
\hline
\end{tabular}

district with 68,248 cases followed by Petaling Perdana with 45,551 cases and Klang with 29,990 cases.

Lastly, bullying data was acquired from District Education Offices in Hulu Langat. Based on the data that had been obtained, there are 39 schools that under the management of District Education Offices Hulu Langat. Six schools are excluded from case study selection due to the factors of boarding school, national type school and government-aided schools. Only 33 of public school are included in the selection of site study. Based on Table 4, the bullying cases increase steadily for the past three years in Hulu Langat district's secondary school. In the year 2013, 72 cases of bullying were recorded and increased to 85 cases in the year 2014. The cases continue to increase in the year 2015 with 104 cases were recorded and keep on increasing to 159 until July 2016.

Table 5 shows list of secondary schools in Hulu Langat district corresponding with the bullying cases occur from 2013 until July 2016. Four schools are chosen for the comparison of the study. Two indicated to be highest in bullying cases which are SMK Bandar Rinching and SMK Taman Tasik. SMK Bandar Rinching 
Table 5. Number of bullying cases in secondary school in Hulu Langat District. Source: PPD Hulu Langat, Selangor.

\begin{tabular}{|c|c|c|c|c|c|}
\hline \multirow{2}{*}{ No. } & \multirow{2}{*}{ List of School } & \multicolumn{3}{|c|}{ Year } & \multirow{2}{*}{ Tota } \\
\hline & & 2013 & 2014 & 2015 & \\
\hline 1 & SMK Abdul Jalil & 1 & & 9 & 10 \\
\hline 2 & SMK Bandar Baru Ampang & 8 & 2 & 5 & 15 \\
\hline 3 & SMK Bandar Baru Bangi & 1 & - & - & 1 \\
\hline 4 & SMK Bandar Baru Sungai Long & - & - & - & 0 \\
\hline 5 & SMK Bandar Damai Perdana & - & - & - & 0 \\
\hline 6 & SMK Bandar Rinching & 4 & 24 & 10 & 38 \\
\hline 7 & SMK Bandar Seri Putra & 2 & 1 & - & 3 \\
\hline 8 & SMK Bandar Tasik Kesuma & 5 & - & 1 & 6 \\
\hline 9 & SMK Bandar Tun Hussein Onn 2 & - & 5 & 5 & 10 \\
\hline 10 & SMK Cheras Jaya & 1 & 1 & 10 & 12 \\
\hline 11 & SMK Cheras Perdana & - & - & - & 0 \\
\hline 12 & SMK Dato Ahmad Razali & - & 4 & - & 4 \\
\hline 13 & SMK Desa Serdang & - & 5 & - & 5 \\
\hline 14 & SMK Dusun Nanding & - & 2 & 5 & 7 \\
\hline 15 & SMK Engku Husain & - & - & 1 & 1 \\
\hline 16 & SMK Jalan Bukit & 9 & 2 & 13 & 24 \\
\hline 17 & SMK Jalan Empat & - & - & - & 0 \\
\hline 18 & SMK Jalan Reko & 2 & 1 & 3 & 6 \\
\hline 19 & SMK Jalan Tiga & 2 & 1 & 2 & 5 \\
\hline 20 & SMK Kajang Utama & - & 1 & 6 & 7 \\
\hline 21 & SMK Khir Johari & 5 & 1 & 3 & 9 \\
\hline 22 & SMK Pandan Indah & 3 & 2 & - & 5 \\
\hline 23 & SMK Pandan Jaya & - & - & 4 & 4 \\
\hline 24 & SMK Pandan Mewah & - & - & 1 & 1 \\
\hline 25 & SMK Sujana Impian & - & 1 & - & 1 \\
\hline 26 & SMK Sultan Abdul Aziz Shah & 3 & - & 2 & 5 \\
\hline 27 & SMK Taman Jasmin 2 & - & - & 1 & 1 \\
\hline 28 & SMK Taman Kosas & 10 & 6 & - & 16 \\
\hline 29 & SMK Taman Perimbun & - & - & 1 & 1 \\
\hline 30 & SMK Taman Seraya & 2 & - & - & 2 \\
\hline 31 & SMK Taman Tasik & 9 & 9 & 10 & 28 \\
\hline 32 & SMK Tasek Permai & - & - & - & 0 \\
\hline \multirow[t]{2}{*}{33} & SMK Tinggi Kajang & - & 1 & 1 & 2 \\
\hline & Total & 67 & 69 & 93 & 229 \\
\hline
\end{tabular}


is chosen as the location of the case study because of the number bullying occur suddenly increase in the year 2015 from one case to 10 cases and keep on the increase in the year 2016. SMK Taman Tasik is chosen as the location of the case study due to the bullying cases that are maintained in the same range between 9 to 10 each year. SMK Cheras Perdana and SMK Jalan Empat are chosen as the comparison for the school in term of lowest bullying occurs. The population of this study consists of four secondary schools in Selangor state which are SMK Cheras Perdana, SMK Taman Tasik and SMK Bandar Rinching and SMK Jalan Empat. The studied school has a mixture genders and ethnic.

Towards achieving the objective, 406 respondents were randomly selected from four secondary schools in Hulu Langat Selangor and 32 blocks of the school building. The respondents involved in this pilot survey were students from the lower form. The survey was done for a period of five days, beginning at $7.20 \mathrm{am}$ until $6.45 \mathrm{pm}$ as the school involve two sessions. The morning session of the school involved Form Three, Form Four and Form Five. Meanwhile, the evening session of the school involved Form One and Form Two. However, the respondent is from Form 1, Form 2 and Form 3. One class from each form was randomly chosen in each school and the questionnaire randomly distributed to the respondent in the class involved. Duration of $10-15$ minutes was required for each respondent to fill the respected questionnaire forms. The measurement design of the sense of safety in school components was based on the review of previous literature that is relevant to the sense of safety in school components.

In order to examine the effect of physical environment on school bullying, the variable will be measure based on CPTED element which was territoriality, surveillance, and maintenance. School level territoriality is operationalized with two different measures which are symbolization element and ownership element. The element is measured based on the number of the element. The indicators of the ownership are sculptures, school field, garden furniture and mural. School level surveillance is measured based on the observation of a building on how it will give the opportunity to student bullying another student. The item is asked about the hidden corner, the visibility of the building from another, the provision of lamps, the visibility of school activity area and the design of the building. The scale were coded 1 = very unsatisfied which refers to the ability of vision between $0-20$ percent, 2 = dissatisfied which refers to the ability of vision between $21-40$ percent, $3=$ neither satisfied nor dissatisfied which refers to the ability of vision between $41-60$ percent, $4=$ satisfied which refers to the ability of vision between $61-80$ percent and $5=$ very satisfied which refers between 80 100 percent. Meanwhile, school level maintenance is measured by observation of 7 elements of school disorder. The school disorder is including, the presence of graffiti, litter, broken window, and broken doors. The response of the item is the same as the surveillance scale. The scale had been adapted from Sakip, et al. (2012) study on CPTED and fear of crime.

The dependent variables for this analysis were based on the probability of a student being bullied which involving the frequency of a student been bullied for 
the past six months. The questions were based on three types of bullying which were; physical bullying (PV), verbal bullying (VB) and relational bullying (RB). In this section contain 15 items that divided into three sub-scale which are physical bullying, verbal bullying and antisocial bullying. The response was range from $1=$ never, $2=$ once a month, $3=2$ to 3 times a month, $4=$ once a week and $5=2$ to 3 times a week. The questions were asked in Bahasa Melayu which is reliable with the school type.

\section{Data Analysis}

Reliability test was performed using Cronbach's alpha for determining the reliability of the items tested (Coakes, Steed, \& Dzidic; 2006; Piaw, 2006). There are 15 items under bullying behaviour which are 5 items under physical bullying, verbal bullying and relational bullying. Meanwhile, there are 10 items under surveillance element and 7 items under maintenance elements. Three items which were two from physical bullying and one from surveillance variables were rejected due to a lower score in corrected item-total correlation. The items with a value of Cronbach's $\alpha$ greater than 0.7 were selected because of acceptable reliability values (Nunnally, 1978; Mackenzie, Podsakoff and Podsakoff, 2011). Reliability tests performed as shown in Table 6 obtained the value of $\alpha>0.70$.

Thus, 31 items from questionnaire and observation form were accepted in the analysis and can be used in the analysis.

Demographics data such as school name, gender, form and race were obtained from the respondents. Table 7 shows the demographic data of the study. The sample of the study consisted of four secondary schools with 81 (20\%) respondent from Sekolah Menengah Kebangsaan Jalan Empat (SMKJE), 96 (23.6\%) respondents from Sekolah Menengah Kebangsaan Cheras Perdana (SMKCP), 119 (29.3\%) respondent from Sekolah Menengah Kebangsaan Taman Tasik (SMKTT) and $110(27.1 \%)$ respondents from Sekolah Menengah Kebangsaan Bandar Rinching (SMKBR). The gender analysis showed that the study consist of $180(44.3 \%)$ male students and 226 (55.7\%) female students. Analysis from the respondent showed that $113(27.8 \%)$ respondent from Form One students, 105 (25.9\%) respondents from Form Two students and 188 (46.3\%) respondents from Form Three students. This study also showed that the respondents came from three different races, where the majority of them were Malays with a number of $303(74.6 \%)$ respondents, 56 (13.8\%) respondent were Chinese and 43 (10.6\%) respondents were Indian. While the other $1 \%$ respondent were from other races such as Sikh, Orang Asli and Iban.

\section{Dependent Variable}

\section{Bullying Behavior}

The statistical analyses by ANOVA and Tukey's multiple comparison tests were carried out for the four different school on the three types of bullying behaviour. Treatment effects were considered significant at $P<0.05$ (Snedecor and Cochran, 1967). An analysis of variance in Table 8 showed that the effect of dif- 
Table 6. Reliability Test of Variables.

\begin{tabular}{|c|c|c|c|c|}
\hline Dependent Variables & Items & Description of Items & $\begin{array}{l}\text { Corrected } \\
\text { item-total } \\
\text { correlation }\end{array}$ & $\begin{array}{c}\text { Reliability } \\
\text { (Cronbach's } \\
\text { Alpha) }\end{array}$ \\
\hline \multirow{6}{*}{ Physical Bullying } & Item 1 & How often other students hitting you in school? & 0.57 & \multirow{6}{*}{0.73} \\
\hline & Item 2 & How often other students kick you in school? & 0.71 & \\
\hline & Item 3 & How often other students pushing you in school? & 0.61 & \\
\hline & Item 4 & How often other students take or breaking your belonging in school? & - & \\
\hline & Item 5 & How often other students making rude hand gesture to you in school? & - & \\
\hline & Item 1 & How often other student making fun and teasing you in a hurtful way in school? & 0.60 & \\
\hline \multirow{4}{*}{ Verbal Bullying } & Item 2 & How often other students calling you mean names in school? & 0.62 & \multirow{4}{*}{0.71} \\
\hline & Item 3 & How often other students calling mean names about your race and skin in school? & 0.68 & \\
\hline & Item 4 & How often other students calling mean names about your race and skin in school? & 0.73 & \\
\hline & Item 5 & How often other students taunting you in school? & 0.63 & \\
\hline \multirow{5}{*}{ Relational Bullying } & Item 1 & How often other students leave you out on purpose in school? & 0.75 & \multirow{5}{*}{0.78} \\
\hline & Item 2 & How often other students telling other not to be friends with you in school? & 0.75 & \\
\hline & Item 3 & How often other students spreading rumours about you in school? & 0.72 & \\
\hline & Item 4 & How often other students embarrassing you in school? & 0.71 & \\
\hline & Item 5 & How often other students criticizing you for making you feel bad in school? & 0.75 & \\
\hline \multirow{11}{*}{ Surveillance } & & Observation of school block & & \multirow{11}{*}{0.72} \\
\hline & Item 1 & $\begin{array}{l}\text { Based on the design of building blocks, the percentage rate allows for the occurrence of } \\
\text { bullying }\end{array}$ & 0.70 & \\
\hline & Item 2 & $\begin{array}{l}\text { Based on the planted element of the plant, the percentage rate allows for visual oppor- } \\
\text { tunities towards the school area }\end{array}$ & - & \\
\hline & Item 3 & Ability or chance of bullies to bully in hidden corners & 0.70 & \\
\hline & Item 4 & Provision of fluorescent lamps either on the bend & 0.68 & \\
\hline & Item 5 & Provision of fluorescent lamps on stairs & 0.75 & \\
\hline & Item 6 & $\begin{array}{l}\text { The visual rate of the classroom position can be seen from the direction of the building } \\
\text { block }\end{array}$ & 0.63 & \\
\hline & Item 7 & The visibility of the building blocks can be seen from the teacher's room & 0.67 & \\
\hline & Item 8 & The visibility of the open spaces with building blocks & 0.69 & \\
\hline & Item 9 & Preparation of CCTV in hidden path/stairs/corners & 0.72 & \\
\hline & Item 10 & The visibility of the activity placement can be seen from the building blocks & 0.65 & \\
\hline \multirow{7}{*}{ Maintenance } & Item 1 & $\begin{array}{l}\text { Planting elements in the building block area whether vegetation cover, shrubs, turf grass } \\
\text { and trees are well maintained }\end{array}$ & 0.82 & \multirow{7}{*}{0.80} \\
\hline & Item 2 & $\begin{array}{l}\text { Toilets in the building block are in good condition without graffiti, garbage, damage, } \\
\text { and paint on the walls in good condition }\end{array}$ & 0.81 & \\
\hline & Item 3 & Paint condition in building blocks in good condition without graffiti & 0.74 & \\
\hline & Item 4 & The room door at school is in good shape & 0.77 & \\
\hline & Item 5 & All windows in school are in good condition & 0.77 & \\
\hline & Item 6 & $\begin{array}{c}\text { The lane paths of the school are in good condition without graffiti, garbage, damage, } \\
\text { and paint on the walls in good condition }\end{array}$ & 0.72 & \\
\hline & Item 7 & Garbage is well maintained in building blocks & 0.73 & \\
\hline
\end{tabular}


Table 7. Demographic Distribution.

\begin{tabular}{cccc}
\hline \multirow{2}{*}{ Criteria } & & $\begin{array}{c}\text { Total No. } \\
(n=406)\end{array}$ & $\begin{array}{c}\text { Percentage } \\
(\%)\end{array}$ \\
\hline \multirow{3}{*}{ School } & Sekolah Menengah Kebangsaan Jalan Empat (SMKJE) & 81 & 20.0 \\
& Sekolah Menengah Kebangsaan Cheras Perdana (SMKCP) & 96 & 23.6 \\
& Sekolah Menengah Kebangsaan Taman Tasik (SMKTT) & 119 & 29.3 \\
& Sekolah Menengah Kebangsaan Bandar Rinching (SMKBR) & 110 & 27.1 \\
\multirow{3}{*}{ Gender } & Male & 180 & 44.3 \\
& Female & 226 & 55.7 \\
& Form 1 & 113 & 27.8 \\
& Form 2 & 105 & 25.9 \\
& Form 3 & 188 & 46.3 \\
& Malay & 303 & 74.60 \\
& Chinese & 56 & 13.80 \\
& Indian & 43 & 10.60 \\
& Others & 4 & 1.0 \\
\hline
\end{tabular}

Table 8. Bullying behaviour in four different school.

\begin{tabular}{ccccccc}
\hline & & \multicolumn{5}{c}{ ANOVA } \\
\cline { 3 - 7 } & & Sum of Squares & df & Mean Square & F & Sig. \\
\hline \multirow{3}{*}{ Relational Bullying } & Between Gorups & 101.291 & 3 & 33.764 & 3.035 & 0.29 \\
& Within Groups & 4371.339 & 393 & 11.123 & & \\
& Total & 4472.630 & 396 & & & \\
\hline
\end{tabular}

ferent school environment on relational bullying was significant $(F(3,393)=$ $3.035, p=0.029)$. The schools that had significantly differences in verbal bullying are SMKJE and SMKTT. The different bullying behaviour in physical bullying and relational bullying may be due to a different environment that exists in each school. Improper landscaping and building design may give the opportunity to the student to bullying other. Differently, with verbal bullying, it can be done quietly and covertly where the children are able to avoid detection and punishment (Atlas \& Pepler, 1998). Despite reaching statistical significance, the actual difference in mean score between the groups was quite small. The effect size, calculated using eta squared as below, was 0.02 .

$$
\text { Eta squared }=\frac{101.291}{4472.630}=0.02
$$

\section{Independent Variable}

Territoriality

A total of 32 blocks in four schools were observed to indicate the element of territoriality that exists in each school. Table 9 showed result from the observation indicated that there were 7 blocks in SMKJE with a total of 273 territoriality 
Table 9. Territoriality element per block in four schools.

\begin{tabular}{cccccc}
\hline \multirow{2}{*}{ School } & Total Block & \multicolumn{2}{c}{ Territoriality Element } & Total & $\begin{array}{c}\text { Territoriality element } \\
\text { per block }\end{array}$ \\
\cline { 3 - 4 } & & Signage & Ownership & & 39 \\
\hline SMKJE & 7 & 38 & 235 & 273 & 21.67 \\
SMKCP & 9 & 14 & 181 & 195 & 12 \\
SMKTT & 10 & 23 & 97 & 120 & 31.33 \\
SMKBR & 6 & 14 & 174 & 188 & \\
Total & 32 & 89 & 687 & 776 & \\
& & & & &
\end{tabular}

Table 10. One-way ANOVA Tests between four different schools with surveillance principle.

\begin{tabular}{cccccc}
\hline & \multicolumn{5}{c}{ ANOVA } \\
\cline { 2 - 6 } & Sum of Squares & df & Mean Square & F & Sig. \\
\hline Between Gorups & 81.808 & 3 & 27.269 & 1.157 & .348 \\
Within Groups & 542.192 & 23 & 23.574 & & \\
Total & 624.000 & 26 & & & \\
\hline
\end{tabular}

Table 11. One-way ANOVA Tests between four different schools with maintenance principle.

\begin{tabular}{cccccc}
\hline & \multicolumn{5}{c}{ ANOVA } \\
\cline { 2 - 6 } & Sum of Squares & df & Mean Square & F & Sig. \\
\hline Between Gorups & 166.684 & 3 & 55.561 & 11.270 & $0.000^{\mathrm{a}}$ \\
Within Groups & 113.390 & 23 & 4.930 & & \\
Total & 280.074 & 26 & & & \\
\hline
\end{tabular}

$\mathrm{a}=$ means are significantly different at $p<0.05$.

element, 9 blocks in SMKCP with 195 elements, 10 blocks in SMKTT with 120 elements and 6 blocks in SMKBR with 188 elements. Calculation of territoriality element per block resulting 39 elements per block in SMKJE, 21.67 elements per block in SMKCP, 12 elements per block in SMKTT and 31.33 elements per block in SMKBR.

Based on the observation of territoriality element in four schools, SMKJE and SMKBR had more sense of school ownership in giving of student good school environment compare with SMKCP and SMKTT. This was shown by the numbers of territoriality element per block in the school.

\section{Surveillance \& Maintenance}

Analysis by ANOVA and Tukey's multiple comparison tests were carried out for the four different schools once again. The objectives of this analysis are to know whether it is different in surveillance and maintenance in four different schools. An analysis of variance in Table 10 showed that the effect of different school environment on surveillance was statistically not significant $(\mathrm{F}(3,28)=$ $0.637, p=0.598$ ).

But, Table 11 shows that there was significantly different in school maintenance in three different schools $(\mathrm{F}(3,28)=11.683 p=0.00)$. The schools that had 
different maintenance are SMKJE, SMKCP and SMKTT.

Based on the four analysis that had been done, SMKJE and SMKTT mostly had significant differences in overall school environment based on three CPTED principle. Territoriality principle is closely related to maintenance principle in presence sense of ownership in school. A significant difference was showed in relational bullying in which occur when the students were socializing among the others. Thus, this study showed that there is a possibility the actual physical environment in which students spend the greater part of their day can affect behaviour, which in turn, can lead to school violence.

\section{Discussion}

The purpose of this paper was to determine if there is a possibility the actual physical environment in which students spend the greater part of their day can affect behaviour, which in turn, can lead to school violence. Table 6 showed the analysis of bullying behaviour in four secondary schools. There are significantly different in relational bullying in SMKJE and SMKTT. The studied schools consist of multi-ethnic and Multilanguage environments, which there is a possibility that particular ethnic or linguistic group likely to be victims. The physical environment in school is believed to be related to developing students behaviour in school (Durán-Narucki, 2008; Liebermann \& Kruger, 2004). This finding suggests that different school environment could influence students' interaction and relation with each other. The finding similar with Mohamad Salleh and Zainal (2014) and Rigby (2008) that showed the indirect bullying was the most widely performed compared with direct bullying. Relational bullying is a group process that difficult to see in adults. The schools that had significantly differences in relational bullying are SMKJE and SMKTT.

Figure 1 and Figure 2 showed school maps of SMKJE and SMKTT. From the observation of the maps, there is different in school building arrangement which had possibility leads to different interaction between the students during the recess time. The arrangement of SMKTT building that scattered makes it difficult for adults to monitor compared with the arrangement of SMKJE building which is more organized and compact. The role of building design and layout can affect the behavior of crime (Poyner, 1983; Wilcox, Augustine, \& Clayton, 2006).

Apart from that, the physical environment which forms different school environment may influence the bullying behaviour in school. Tables 9-11 show the findings on physical features in four secondary schools based on three CPTED elements. Based on the finding on territoriality element in Table 9, the result indicated that significantly different in element per block between SMKJE and SMKTT. SMKJE had more physical features with seven blocks of school building compared with SMKTT which had ten blocks of school building but less element per block.

Figure 3 and Figure 4 showed territorial element features like signage and 
A. A. Wahab et al.

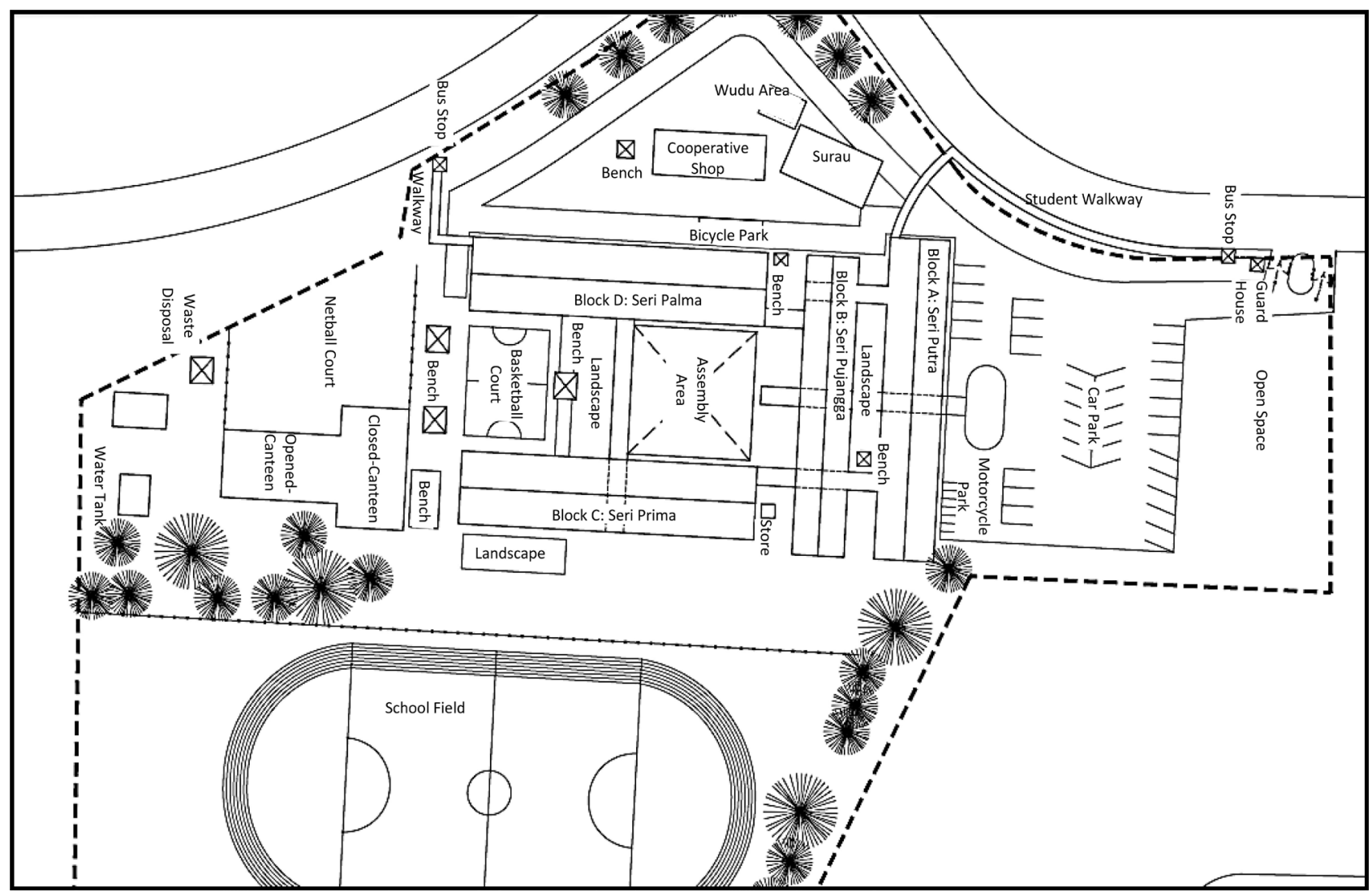

Figure 1. SMKJE school map.

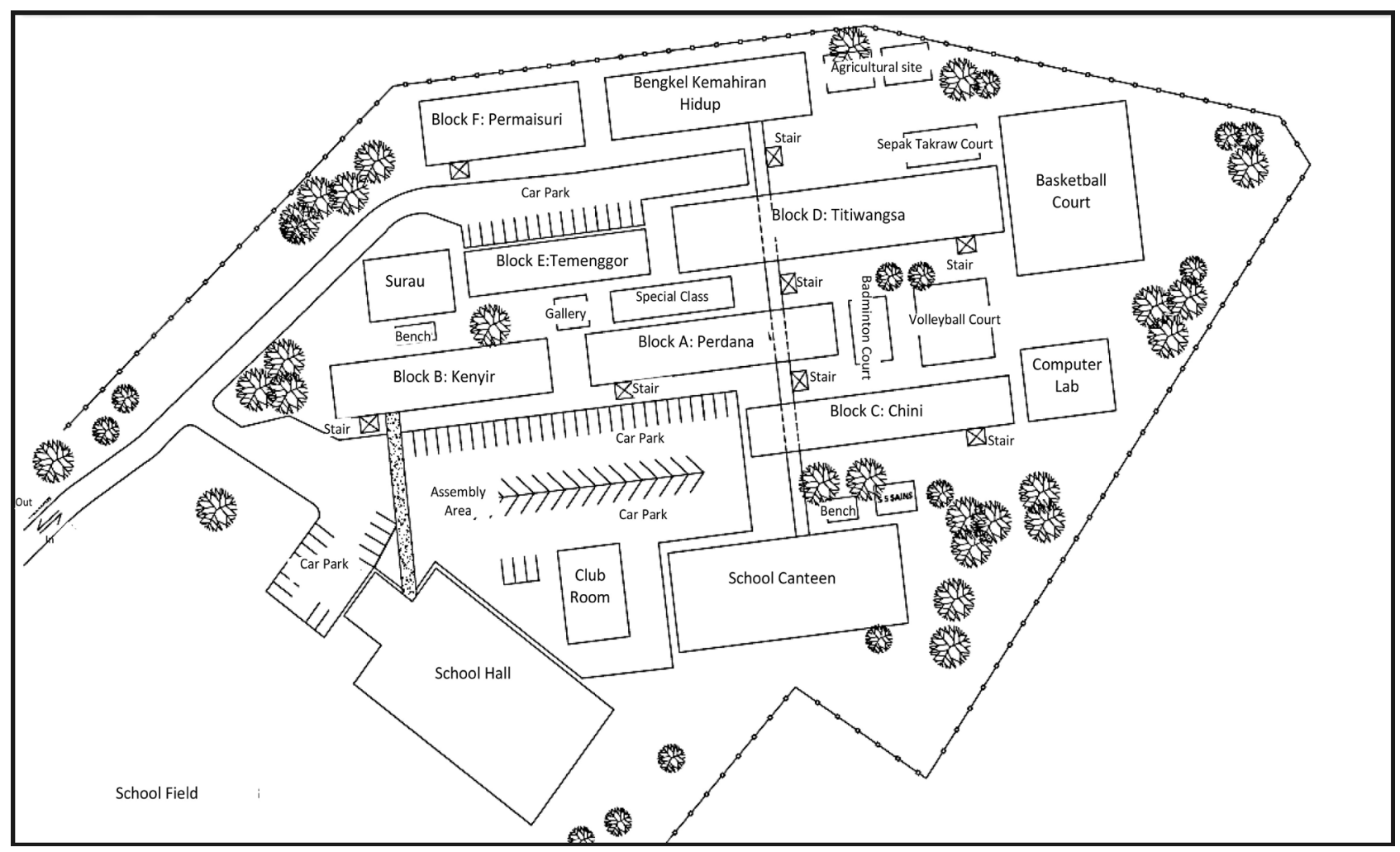

Figure 2. SMKTT school map. 


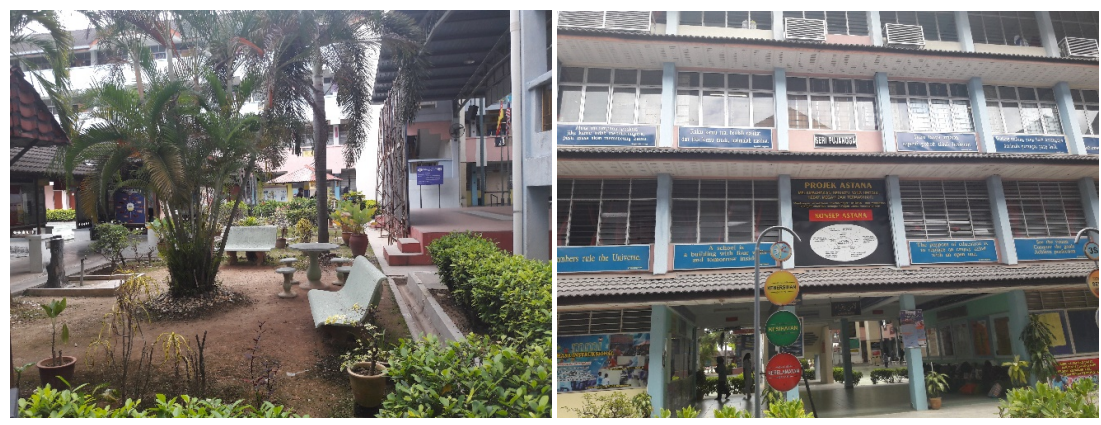

Figure 3. The features of territoriality element in SMKJE.

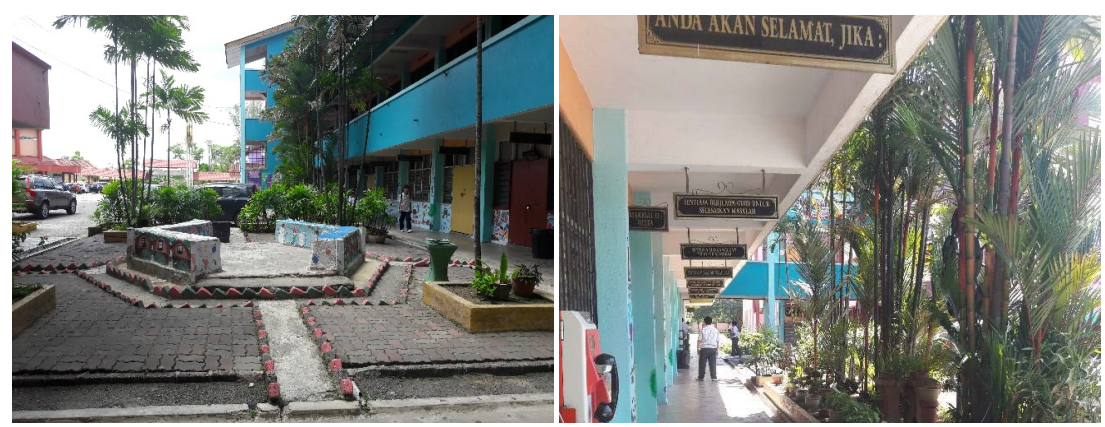

Figure 4. The features of territoriality element in SMKTT.

sculptures. From the observation in the schools, SMKJE set more resting place for a student to socialize with each other compared with SMKTT. A good conducive landscaped is believed to directly or indirectly assists in providing space for leisure and interacting with landscape components (Ali, Rostam, \& Awang, 2015). This paper may have proven that the level of certain components of landscapes at the school in the region is significant can create a sense of ownership by setting up gazebo, pergola, bench, garden tables, signboards and flower pots. Schools that include permanent student artwork in the interior spaces of school buildings also will foster student ownership (Killeen, Evans, \& Danko, 2003). This can be proved by the mean $(\mu)$ value of relational bullying in SMKTT is higher $(\mu=1.52)$ than in SMKJE $(\mu=1.32)$.

However, even though the school layout and design were different in each school, but the in monitoring each building can be done. This finding was showed in Table 10 which indicated that there was no significant difference in the surveillance element. The visibility of the activity placemen, open space and classroom can be seen from the buildings block. The chances of bullies to bully in the hidden corner are less. Although most of the exterior spaces of the schools are a high-visibility area, there were few respondents respond that the hottest spots were behind the buildings area. This finding tends to support previous studies which indicated that there was low visibility behind the school building (Lee \& Ha, 2015).

Meanwhile, Table 11 showed significant differences in maintenance element in SMKCP, SMKJE and SMKTT. This finding would like to focus on the maintenance in SMKJE and SMKTT as the finding before in bullying behaviour indi- 

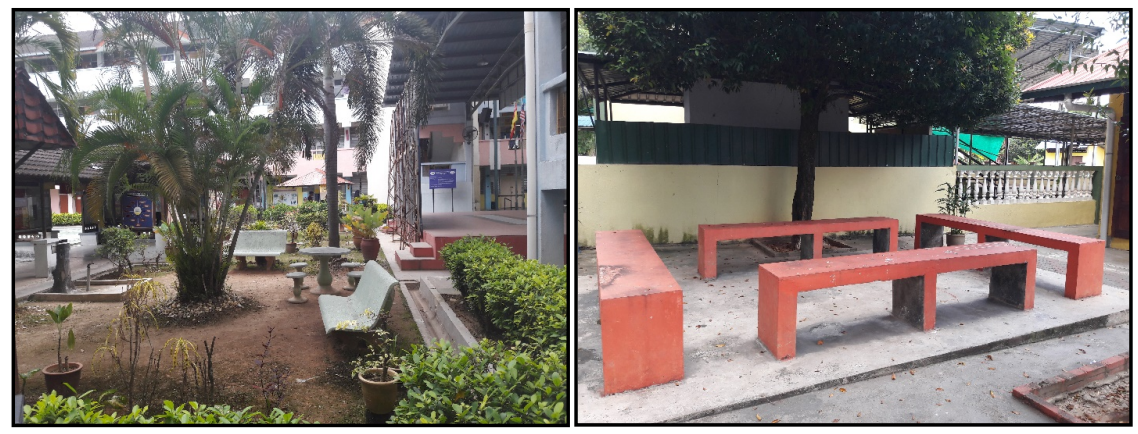

Figure 5. Comparison between bench maintenance in SMKJE and SMKTT.
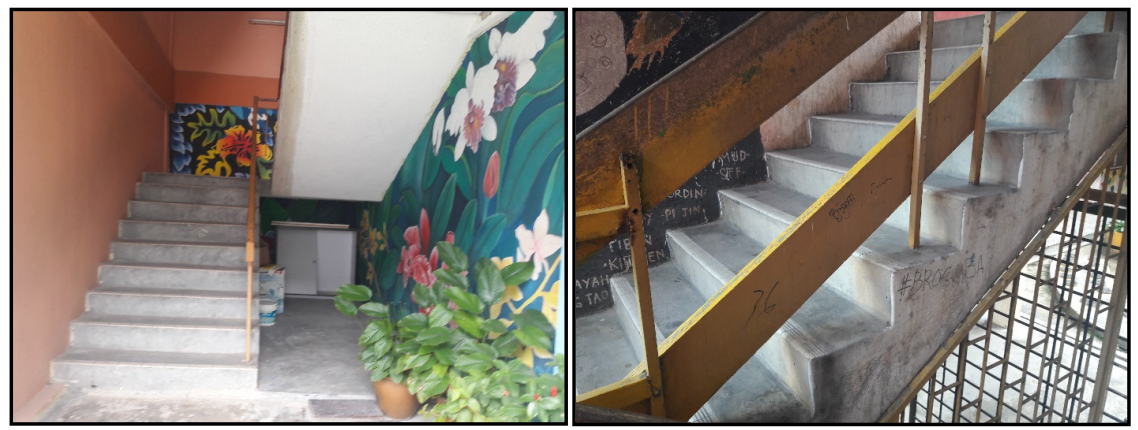

Figure 6. Comparison between stair maintenance in SMKJE and SMKTT.

cated that significantly different in those schools. The result on maintenance level in SMKJE showed that the level was $61 \%$ to $80 \%$. Meanwhile, the level of maintenance in SMKTT was $41 \%$ to $60 \%$.

Figure 5 and Figure 6 were a comparison between the bench and stairs between both schools. Paint condition in SMKTT stairs was not in good condition with graffiti compare with SMKJE. The bench for the student to sit also not in good condition in SMKTT with bird dropping on it. Even though the element of plants were also had at SMKJE bench, but the bench was in good condition. Lacks maintenance in SMKTT may develop bullying behaviour similarly with the previous study by (Lorenc, et al., 2013; Wilcox, et al., 2006). Dirt, decay, graffiti, litter and other sign of the environment are referred as "sign of crime", and people tend to fear with this environment. These findings tend to support previous studies on physical environment and student misconduct by Wilcox, et al. (2006).

\section{Conclusion}

As a whole, there is a possibility the actual physical environment in which students spend the greater of their day can affect bullying behaviour in secondary school. The physical environment surrounding the child has a great influence on his or her development. Well-designed schools can positively affect learning by focusing on issues such as location, building materials, size of classrooms, furniture, lighting, temperature, ventilation and noise level. Bullying in school may be an earlier stage on developmental sequence leading to a strong predictor of de- 
linquency and future crime. The ecological theory suggested that physical characteristic can affect the crime (Shaw \& McKay, 1942). A well-structured school physical environment helps to promote learning and encourage positive social interactions among students. Poor designs such as dim lighting, poor lines of sight and narrow corridors are cited by young people as being to blame for the sense of fear and risk associated with these out of the way places. The physical condition and on-going maintenance of the school building are an important factor in setting a positive school tone. A clean, well-maintained building is fundamental to the creation of an optimal environment for teaching and learning. Lack of monitoring has made these out of the way locations prime spots for vandalism and graffiti and contributing to the feeling of being unsafe. The school community has to focus on developing a good environment in school. Achieving good design and environment is about creating places, buildings, or spaces that work well for everyone, look good, last well, and will adapt to the needs of future generations. Further analysis of regression analysis can be tested between the type of environment in school and the incident of bullying when the other factors such as social status, gender, ethnic and language are controlled.

\section{Limitation}

The study only focuses on secondary school and not involved boarding school and technical school because of similarity spaces that majority of all schools had. Compared with the boarding school, the secondary students tend to have smaller spaces. Boarding school had more spaces to monitor as it involved hostel for students. There are limitations on the school design in obtaining a comprehensive picture of factors associated with bullying victimisation due to the different design and arrangement of school.

\section{Acknowledgements}

In realising this study, the researchers would like to thank the Royal Malaysian Police (PDRM), Ministry of Higher Education by the Malaysian Government in supporting this research by the Fundamental Research Grant Scheme (FRGS) of (FRGS/1/2015/SSI11/UITM/02/12).

\section{References}

Adel, H., Mohamed, S., \& Mahmoud, R. A. (2014). Crime in Relation to Urban Design. Case Study: The Greater Cairo Region. Ain Shams Engineering Journal, 7, 925-938. http://doi.org/10.1016/j.asej.2015.08.009

Ali, S. M., Katiman, R., \& Awang, A. H. (2015). School Landscape Environments in Assisting the Learning Process and in Appreciating the Natural Environment. Procedia-Social and Behavioral Sciences, 202, 189-198. https://doi.org/10.1016/j.sbspro.2015.08.222 http://linkinghub.elsevier.com/retrieve/pii/S1877042815048703

Anastasia, L. S., \& John, E. E. (2007). Crime Prevention and Active Living. American Journal of Health Promotion, 21, 380-389. https://doi.org/10.4278/0890-1171-21.4s.380

Andershed, H., Margaret, K., \& Håkan, S. (2001). Bullying in School and Violence on the 
Streets: Are the Same People Involved? Journal of Scandinavian Studies in Criminology and Crime Prevention, 2, 31-49. https://doi.org/10.1080/140438501317205538

Astor, R. A., Heather, A. M., \& Behre, W. J. (1999). Unowned Places and Times: Maps and Interviews about Violence in High Schools. American Educational Research Journal, 36, 3-42. https://doi.org/10.3102/00028312036001003

Atlas, R. S., \& Debra, J. P. (1998). Observations of Bullying in the Classroom. Journal of Educational Research, 92, 86-99. https://doi.org/10.1080/00220679809597580

Bernama (2017). 402 Sekolah "Hotspot” Babit Kes Salah Laku, Disiplin Pelajar. FMT News.

http://www.freemalaysiatoday.com/category/bahasa/2017/04/25/402-sekolah-hotspot-b abit-kes-salah-laku-disiplin-pelajar

Boulton, M. J., Mark, T., \& Ian, F. (2002). Associations between Secondary School Pupils' Definitions of Bullying, Attitudes towards Bullying, and Tendencies to Engage in Bullying: Age and Sex Differences. Educational Studies, 28, 353-370. https://doi.org/10.1080/0305569022000042390

Bowes, L., et al. (2009). School, Neighborhood, and Family Factors Are Associated with Children's Bullying Involvement: A Nationally Representative Longitudinal Study. Journal of the American Academy of Child and Adolescent Psychiatry, 48, 545-553. https://doi.org/10.1097/CHI.0b013e31819cb017

Cozen, P. M., Greg, S., \& David, H. (2005). Crime Prevention through Environmental Design (CPTED): A Review and Modern Bibliography. Property Management, 23, 328356. https://doi.org/10.1108/02637470510631483

Craig, W. M., Debra, J. P., \& Rona, A. (2000). Observation of Bullying in the Playground and in the Classroom. School Psychology International, 21, 22-36. https://doi.org/10.1177/0143034300211002

Crick, N. R., Jennifer, K. G., Nicki, R. C., \& Grotpeter, J. K. (1995). Social-Psychological Adjustment. Society for Research in Child Development, 66, 710-722.

Durán-Narucki, V. (2008). School Building Condition, School Attendance, and Academic Achievement in New York City Public Schools: A Mediation Model. Journal of Environmental Psychology, 28, 278-286. https://doi.org/10.1016/j.jenvp.2008.02.008

Espelage, D. L., Bosworth, K., \& Simon, T. R. (2000). Examining the Social Context of Bullying Behaviors in Early Adolescence. Journal of Counseling and Development, 78, 326-333.

http://www.scopus.com/inward/record.url?eid=2-s2.0-0034422247\&partnerID=40\&md 5=d689f777ee59c7a011724dc553380ee0

Farrington, D. P., \& Ttofi, M. M. (2011). Bullying as a Predictor of Offending, Violence and Later Life Outcomes. Criminal Behavior and Mental Health, 21, 90-98.

Ghani, Z. A. (2017). A Comparative Study of Urban Crime between Malaysia and Nigeria. Journal of Urban Management, 6, 19-29.

http://linkinghub.elsevier.com/retrieve/pii/S2226585617300274 https://doi.org/10.1016/j.jum.2017.03.001

Grana, R. A., Black, D., Sun, P., Rohrbach, L. A., Gunning, M., \& Sussman, S. (2010). School Disrepair and Substance Use among Regular and Alternative High School Students. Journal of School Health, 80, 387-393.

https://doi.org/10.1111/j.1746-1561.2010.00518.x

Hawker, D. S. J., \& Boulton, M. J. (2000). Twenty Years' Research on Peer Victimization and Psychosocial Maladjustment: A Meta-Analytic Review of Cross-Sectional Studies. Journal of Child Psychology and Psychiatry, 41, 441-455.

https://doi.org/10.1111/1469-7610.00629 
Hughes, M. R., Gaines, J. S., \& Pryor, D. W. (2014). Staying Away from School: Adolescents Who Miss School Due to Feeling Unsafe. Youth Violence and Juvenile Justice, 13, 270-290. https://doi.org/10.1177/1541204014538067

Johnson, S. L. (2009). Improving the School Environment to Reduce School Violence: A Review of the Literature. Journal of School Health, 79, 451-465. https://doi.org/10.1111/j.1746-1561.2009.00435.x

Katherine, J. W. (2013). A Correlational Study of the Levels of School Violence and the School's Physical Environment as Perceived by Teachers.

Killeen, J. P., Evans, G. W., \& Danko, S. (2003). The Role of Permanent Student Artwork in Students' Sense of Ownership in an Elementary School. Environment and Behavior, 35, 250-263. http://journals.sagepub.com/doi/10.1177/0013916502250133 https://doi.org/10.1177/0013916502250133

Kitchen, T., \& Schneider, R. H. (2007). Crime Prevention and the Built Environment. https://books.google.com/books?hl=en\&lr=\&id=oUd_AgAAQBAJ\&oi=fnd\&pg=PP1\& $\mathrm{dq}=$ schneider $+\mathrm{r}+\mathrm{h}+\% 26+$ kitchen $+\mathrm{t}+(2007)+$ crime + prevention $+\mathrm{and}+$ the + built + enviro nment\&ots=Y21W4tnvvH\&sig=A1YRW7UGmif4n_CbPlsKpJD3xQ8

Kumar, R., Malley, P. M. O., \& Johnston, L. D. (2008). Association between Physical Environment of Secondary Schools and Student Problem Behavior. Environment and B, 40, 455-486. http://www.eoearth.org/view/article/155229/

Lee, S., \& Ha, M. (2015). The Duality of Visibility: Does Visibility Increase or Decrease the Fear of Crime in Schools' Exterior Environments? Journal of Asian Architecture and Building Engineering, 14, 145-152.

Liebermann, S., \& Kruger, T. (2004). Crime Prevention through Environmental Design (CPTED). In 9th International Conference on Crime Prevention Environmental Design.

Lorenc, T. et al. (2013). Fear of Crime and the Environment: Systematic Review of UK Qualitative Evidence.

Melde, C., \& Esbensen, F.-A. (2009). The Victim-Offender Overlap and Fear of In-School Victimization. Crime \& Delinquency, 55, 499-525. https://doi.org/10.1177/0011128709335401

Min, J. K., Catalano, R. F., Haggerty, K. P., \& Abbott, R. D. (2011). Bullying at Elementary School and Problem Behaviour in Young Adulthood: A Study of Bullying, Violence and Substance Use from Age 11 to Age 21. Criminal Behaviour and Mental Health, 21, 136-144. https://doi.org/10.1002/cbm.804

Mohamad Salleh, N., \& Zainal, K. (2014). Bullying among Secondary School Students in Malaysia: A Case Study. International Education Studies, 7, 184-191. https://doi.org/10.5539/ies.v7n13p184

Nakamoto, J., \& Schwartz, D. (2010). Is Peer Victimization Associated with Academic Achievement? A Meta-Analytic Review. Social Development, 19, 221-242. https://doi.org/10.1111/j.1467-9507.2009.00539.x

Newman, O. (1972). Defensible Space. https://www.ncjrs.gov/App/Publications/abstract.aspx?ID=39495

Newman-Carlson, D., \& Horne, A. M. (2004). Bully Busters: A Psychoeducational Intervention for Reducing Bullying in Middle School Students. Journal of Counseling \& Development, 82, 259-267. https://doi.org/10.1002/j.1556-6678.2004.tb00309.x

Olweus, D. (1994). Bullying at School. In L. R. Huesmann (Ed.), Aggressive Behavior. The Plenum Series in Social/Clinical Psychology, Boston, MA: Springer.

Olweus, D. (2011). Bullying at School and Later Criminality: Findings from Three Swe- 
dish Community Samples of Males. Criminal Behavior and Mental Health, 21, 151-156.

Olweus, D., \& Mortimore, P. (1993). Bullying at School: What We Know and What We Can Do.

Perkins, D. D., Meeks, J. W., \& Taylor, R. B. (1992). The Physical Environment of Street Blocks and Resident Perceptions of Crime and Disorder: Implications for Theory and Measurement. Journal of Environmental Psychology, 12, 21-34. https://doi.org/10.1016/S0272-4944(05)80294-4

Poyner, B. (1983). Design against Crime: Beyond Defensible Space. https://www.ncjrs.gov/App/Publications/abstract.aspx?ID=92652

Poyner, B. (1993). What Works in Crime Prevention: An Overview of Evaluations. Crime Prevention Studies. $\underline{\text { http://citeseerx.ist.psu.edu/viewdoc/download?doi=10.1.1.437.2189\&rep=rep1\&type }=p}$ df

Raja Zaid, R. H. (2017). Kes Disiplin 402 Buah Sekolah Panas Dan Bermasalah Dikenal Pasti. Astro AWANI.

http://www.astroawani.com/berita-malaysia/kes-disiplin-402-buah-sekolah-panas-danbermasalah-dikenal-pasti-146957

Reijntjes, A., Kamphuis, J. H., Prinzie, P., \& Telch, M. J. (2010). Peer Victimization and Internalizing Problems in Children: A Meta-Analysis of Longitudinal Studies. Child Abuse \& Neglect, 34, 244-252. https://doi.org/10.1016/j.chiabu.2009.07.009

Renda, J., Vassallo, S., \& Edwards, B. (2011). Bullying in Early Adolescence and Its Association with Anti-Social Behaviour, Criminality and Violence 6 and 10 Years Later. Criminal Behaviour and Mental Health, 21, 117-127. https://doi.org/10.1002/cbm.805

Rigby, K. (2003). Consequences of Bullying in Schools. Canadian Journal of Psychiatry, 48, 583-590. https://doi.org/10.1177/070674370304800904

Rigby, K. (2008). Children and Bullying: How Parents and Educators Can Reduce Bullying at School. http://psycnet.apa.org/psycinfo/2007-08903-000

Robers, S., Zhang, A., \& Morgan, R. E. (2015). Indicators of School Crime and Safety: 2014. National Center for Education Statistics.

Roland, E., \& Galloway, D. (2002). Classroom Influences on Bullying. Education Research, 44, 299-312. https://doi.org/10.1080/0013188022000031597

Sakip, S. R. M., Johari, N., \& Salleh, M. N. M. (2012). The Relationship between Crime Prevention through Environmental Design and Fear of Crime. Procedia-Social and Behavioral Sciences, 68, 628-636. https://doi.org/10.1016/j.sbspro.2012.12.254

Shamsuddin, S., Bahauddin, H., \& Abd, N. (2012). Relationship between the Outdoor Physical Environment and Student's Social Behaviour in Urban Secondary School. Procedia-Social and Behavioral Sciences, 50, 148-160.

Shaw, C., \& McKay, H. (1942). Juvenile Delinquency and Urban Areas: A Study of Rates of Delinquents in Relation to Differential Characteristics of Local Communities in American Cities (Behavior Research Fund Monographs). Chicago, IL: University of Chicago Press.

https://usm.on.worldcat.org/search?queryString=no\%3A+384994\#/oclc/384994

Sourander, A. et al. (2011). Bullying at Age Eight and Criminality in Adulthood: Findings from the Finnish Nationwide 1981 Birth Cohort Study. Social Psychiatry and Psychiatric Epidemiology, 46, 1211-1219. https://doi.org/10.1007/s00127-010-0292-1

Vidourek, R. A., King, K. A., \& Merianos, A. L. (2016). School Bullying and Student Trauma: Fear and Avoidance Associated with Victimization. Journal of Prevention \& Intervention in the Community, 44, 121-129. 
https://doi.org/10.1080/10852352.2016.1132869

Wan, I., Wan, S. et al. (2010). School Bullying among Standard Six Students Attending Primary National Schools in the Federal Territory Oo Kuala Lumpur: The Prevalence and Associated Socio Demographic Factors. Malaysian Journal of Psychiatry, 18, 5-12.

Wang, J., Iannotti, R. J., \& Nansel, T. R. (2009). School Bullying among Adolescents in the United States: Physical, Verbal, Relational, and Cyber. Journal of Adolescent Health, 45, 368-375. https://doi.org/10.1016/j.jadohealth.2009.03.021

Wilcox, P., Augustine, M. C., \& Clayton, R. R. (2006). Physical Environment and Crime and Misconduct in Kentucky Schools. The Journal of Primary Prevention, 27, 293-313. https://doi.org/10.1007/s10935-006-0034-z 